\title{
Withania somnifera modulates cancer cachexia associated inflammatory cytokines and cell death in leukaemic THP-1 cells and peripheral blood mononuclear cells (PBMC's)
}

Dhaneshree Bestinee Naidoo', Anil Amichund Chuturgoon', Alisa Phulukdaree', Kanive Parashiva Guruprasad², Kapaettu Satyamoorthy ${ }^{2}$ and Vikash Sewram ${ }^{3,4^{*}}$ (D)

\begin{abstract}
Background: Cancer and inflammation are associated with cachexia. Withania somnifera (W. somnifera) possesses antioxidant and anti-inflammatory potential. We investigated the potential of an aqueous extract of the root of $W$. somnifera $\left(W_{R E}\right)$ to modulate cytokines, antioxidants and apoptosis in leukaemic THP-1 cells and peripheral blood mononuclear cells (PBMC's).

Methods: Cytotoxcity of $W_{R E}$ was determined at 24 and $72 \mathrm{~h}(\mathrm{~h})$. Oxidant scavenging activity of $\mathrm{W}_{\mathrm{RE}}$ was evaluated (2, 2-diphenyl-1 picrylhydrazyl assay). Glutathione (GSH) levels, caspase $(-8,-9,-3 / 7)$ activities and adenosine triphosphate (ATP) levels (Luminometry) were thereafter assayed. Tumour necrosis factor-a (TNF-a), interleukin (IL)-6, IL-1 $\beta$ and IL-10 levels were also assessed using enzyme-linked immunosorbant assay.

Results: At 24 h, W $W_{R E}(0.2-0.4 \mathrm{mg} / \mathrm{ml})$ decreased PBMC viability between 20 and 25\%, whereas it increased THP-1 viability between 15 and 23\% ( $p<0.001)$. At $72 \mathrm{~h}, \mathrm{~W}_{\mathrm{RE}}$ increased PBMC viability by $27-39 \%(0.05,0.4 \mathrm{mg} / \mathrm{ml} \mathrm{W}$ RE) whereas decreased THP-1 viability between 9 and $16 \%\left(0.05-0.4 \mathrm{mg} / \mathrm{ml} \mathrm{W} \mathrm{WE}_{\mathrm{RE}}(p<0.001)\right.$. Oxidant scavenging activity was increased by $W_{R E}(0.05-0.4 \mathrm{mg} / \mathrm{ml}, p<0.0001)$. PBMC TNF- $a$ and IL-10 levels were decreased by $0.2-0.4 \mathrm{mg} / \mathrm{ml} \mathrm{W} \mathrm{W}_{\mathrm{RE}}$, whereas IL-1 $\beta$ levels were increased by $0.05-0.4 \mathrm{mg} / \mathrm{ml} \mathrm{W} W_{\mathrm{RE}}(p<0.0001)$. In THP-1 cells, $W_{\mathrm{RE}}(0.05-0.4 \mathrm{mg} / \mathrm{ml})$ decreased TNF-a, IL-1 $\beta$ and IL-6 levels $(p<0.0001)$. At 24 h, GSH levels were decreased in PBMC's, whilst increased in THP-1 cells by $0.2-0.4 \mathrm{mg} / \mathrm{ml} \mathrm{W} \mathrm{W}_{\mathrm{RE}}(p<0.0001)$. At $72 \mathrm{~h}, \mathrm{~W}_{\mathrm{RE}}(0.1-0.4 \mathrm{mg} / \mathrm{ml})$ decreased GSH levels in both cell lines $(p<0.0001)$. At $24 \mathrm{~h}$, $W_{R E}(0.2-0.4 \mathrm{mg} / \mathrm{ml})$ increased PBMC caspase $(-8,-3 / 7)$ activities whereas $W_{R E}(0.05,0.1,0.4 \mathrm{mg} / \mathrm{ml})$ increased THP-1 caspase $(-9,-3 / 7)$ activities $(p<0.0001)$. At $72 \mathrm{~h}$, PBMC caspase $(-8,-9,-3 / 7)$ activities were increased at $0.05-0.1 \mathrm{mg} / \mathrm{ml} \mathrm{W} \mathrm{WE}_{\mathrm{RE}}$ $(p<0.0001)$. In THP-1 cells, caspase $(-8,-9,-3 / 7)$ activities and ATP levels were increased by $0.1-0.2 \mathrm{mg} / \mathrm{ml} \mathrm{W}_{\mathrm{RE}}$, whereas decreased by 0.05 and $0.4 \mathrm{mg} / \mathrm{ml} \mathrm{WRE}(72 \mathrm{~h}, p<0.0001)$.

Conclusion: In PBMC's and THP-1 cells, $W_{R E}$ proved to effectively modulate antioxidant activity, inflammatory cytokines and cell death. In THP-1 cells, WRE decreased pro-inflammatory cytokine levels, which may alleviate cancer cachexia and excessive leukaemic cell growth.
\end{abstract}

Keywords: Cancer, Cachexia, Cytokines, Apoptosis, Withania somnifera

\footnotetext{
* Correspondence: vsewram@sun.ac.za

${ }^{3}$ African Cancer Institute, Stellenbosch University, P.O. Box 241, Cape Town 8000, South Africa

${ }^{4}$ Department of Global Health, Faculty of Medicine and Health Sciences,

Stellenbosch University, P.O. Box 241, Cape Town 8000, South Africa

Full list of author information is available at the end of the article
}

(c) The Author(s). 2018 Open Access This article is distributed under the terms of the Creative Commons Attribution 4.0 International License (http://creativecommons.org/licenses/by/4.0/), which permits unrestricted use, distribution, and reproduction in any medium, provided you give appropriate credit to the original author(s) and the source, provide a link to the Creative Commons license, and indicate if changes were made. The Creative Commons Public Domain Dedication waiver (http://creativecommons.org/publicdomain/zero/1.0/) applies to the data made available in this article, unless otherwise stated. 


\section{Background}

Chronic inflammation plays an essential role in malignancies [1] through the initiation, promotion and progression of tumours [2]. Usually, the host-mediated anti-tumour activity overcomes the tumour-mediated immunosuppressive activity leading to the elimination of cancerous cells [2]. However, in the presence of an inadequate host antitumour defence, the pro-inflammatory tumour microenvironment is enhanced and promotes tumour development, invasion, angiogenesis and metastasis [2].

The cachectic syndrome is prominent in malignancies occurring in up to $50 \%$ of all cancer patients [3]. It is a progressive, debilitating condition leading to abnormal weight loss, as a result of adipose tissue (85\%) and skeletal muscle (75\%) depletion [3-5]. Modulation of lipogenesis and lipolysis is essential in maintaining adipose tissue mass. Lipoprotein lipase (LPL) hydrolyses fatty acids (FA's) from plasma lipoproteins, thereafter FA's are transported to adipose tissue for triacylglycerol (TAG) production, whereas hormone sensitive lipase (HSL) hydrolyses TAG's into FA's and glycerol [3]. Literature shows that decreased serum LPL levels/activity and increased HSL levels/activity are associated with cachexia [6-8]. Additionally, increased proteolysis [9] and decreased proteogenesis has been established in cachectic patients [10]. The ATP-ubiquitin-dependent proteolytic pathway has been shown to be responsible for the accelerated proteolysis seen in a variety of wasting conditions, including cancer cachexia [11].

Inflammatory cytokines, oxidative stress and apoptosis have been implicated in the initiation and progression of cancer, imbalance of catabolic/anabolic processes [12] and development of cachexia [13]. Production of inflammatory cytokines [tumour necrosis factor- $\alpha$ (TNF- $\alpha$ ), interleukin (IL) -6 , and IL-1 $\beta$ ] is activated by lipopolysaccharide (LPS) that potently stimulates macrophages $[14,15]$. The LPS signal is transduced by LPS binding to LPS binding protein, delivered to CD14 and transferred to Toll like receptor-4 [16]. Nuclear factor kappa B (NF$\kappa \mathrm{B})$ is subsequently activated and regulates the transcription of genes associated with inflammation, proliferation, invasion, angiogenesis and apoptosis [1, 17-19]. Proinflammatory cytokines (TNF- $\alpha$, IL- 6 and IL-1) have been shown to decrease LPL activity [20-23], which reduces the uptake of exogenous lipids by adipose tissue [21], ultimately decreasing lipogenesis. Additionally, previous studies have indicated that TNF- $\alpha$ increased ubiquitin (concentrations and mRNA), while IL-6 increased the $26 \mathrm{~S}$ proteasome and cathepsins activities, which may activate proteolytic pathways [4, 24-26], ultimately increasing proteolysis. In combination, excessive levels of pro-inflammatory cytokines increase tumour suppressive activity [2] and tissue wasting [3].

Reactive oxygen species (ROS) have been associated with tumour initiation, inflammation $[2,27]$ and muscle wasting [28]. However, antioxidants have been shown to decrease muscle wasting by neutralizing $\operatorname{ROS}[1,28]$. Elevated ROS levels activate apoptotic pathways, ultimately activating caspase-3 [29]. Caspase-3 activation plays an essential role in the execution of apoptosis, as well as muscle proteolysis [30]. In addition, in weight losing upper gastro-intestinal tract cancer patients, deoxyribonucleic acid (DNA) fragmentation and poly (ADP-ribose) polymerase (PARP) cleavage were increased, whereas MyoD protein was decreased, indicating increased apoptosis and decreased muscle replenishment [3].

Cancer patients suffer from a wide range of side-effects caused by current cancer chemotherapeutic and radiotherapeutic agents. Patients are constantly seeking alternative traditional remedies to alleviate their discomfort. Withania somnifera (L.) Dunal (W. somnifera) is a well known medicinal plant cultivated in India, parts of East Asia and Africa [31]. It is commonly referred to as Ashwagandha and belongs to the Solanaceae family [31]. Compounds isolated from $W$. somnifera include withaferin A and 3- $\beta$-hydroxy2, 3 dihydro withanolide $F$ [32]. The major constituent of the root extract of $W$. somnifera is withanolide-A [33]. W. somnifera is frequently used in Ayurvedic medicine due to its various medicinal properties [31]. These properties include anti-inflammatory [34], antioxidant and immunemodulatory activities [35]. W. somnifera was found to be an immune regulator in inflammation animal models [36]. The immunosuppressive action of $W$. somnifera may be due to the presence of withanolides, steroidal lactones and a few flavanoids [37]. In addition, W. somnifera formulation (WSF) has shown anti-proliferative potential in human promyelocytic leukemia (HL-60) cells, by activating the intrinsic and extrinsic apoptotic pathways [38]. When used together, $W$. somnifera formulations aid the host to effectively fight cancer and reduce the harmful effects of chemotherapy and radiotherapy [39].

There is a need for the discovery of an inexpensive cancer cachectic treatment to improve the prognosis of cancer patients and to establish a mechanism of regulation of the immune system, inflammasome and apoptosis in order to prevent/decelerate the rapid depletion of skeletal muscle and adipose tissue. We investigated the effect of an aqueous extract of the root of $W$. somnifera $\left(\mathrm{W}_{\mathrm{RE}}\right)$ on antioxidant capacity, inflammatory cytokine levels and cell death induction in leukaemic THP-1 cells and peripheral blood mononuclear cells (PBMC's).

\section{Methods}

\section{Materials}

The roots of $W$. somnifera were collected on the 11th of March 2011 (collectors number: Immelman 427) from the Eastern Cape [the Ntubeni Location near Dwesa Reserve], South Africa (SA) and identified by Dr. Kathleen Immelman from the Department of Botany at the Walter Sisulu 
University, SA and further comparison to South African data [40]. Voucher specimens were deposited at the KEI herbarium (13995). THP-1 cells were obtained from from American Type Culture Collection (ATCC, University Boulevard Manassas, Virginia, USA). RPMI-1640 and BD OptEIA enzyme-linked immunosorbant assay (ELISA) cytokine kits were purchased from The Scientific Group (Johannesburg, SA). Foetal calf serum (FCS) and Pen/ Strep Amphotericin B (PSF) were acquired from Whitehead Scientific (Cape Town, SA). Dimethyl sulphoxide (DMSO) was purchased from Merck (Johannesburg, SA). Histopaque-1077, LPS and 2, 2-diphenyl-1 picrylhydrazyl (DPPH) were purchased from Sigma (Aston Manor, SA). The 4-[3-(4-iodophenyl)-2-(4-nitrophenyl)-2H-5-tetrazolio]1,3-benzene disulphonate (WST-1) cell proliferation reagent was purchased from Roche (Johannesburg, SA). Promega (Madison, USA) supplied the caspase $(-3 / 7$, $-8,-9)$, adenosine triphosphate (ATP) and glutathione (GSH) kits.

\section{Plant extraction}

The roots of W. somnifera were dried and milled before being sequentially extracted in ethanol and distilled water. Ethanol (200-350 ml) was added to the milled root (10$30 \mathrm{~g})$ and extracted overnight by shaking $\left(4 \times \mathrm{g}, 37^{\circ} \mathrm{C}\right)$. The ethanol extracts were thereafter filtered, evaporated using a rotary evaporator, dried $\left(37^{\circ} \mathrm{C}\right)$ and stored $\left(4{ }^{\circ} \mathrm{C}\right)$. The root material was thereafter extracted with distilled water (200-350 ml) by shaking $\left(4 \times \mathrm{g}, 75{ }^{\circ} \mathrm{C}\right)$ for a period of 6 hours (h). Water extracts were filtered, dried and stored $\left(4{ }^{\circ} \mathrm{C}\right)$.

\section{The 2, 2-diphenyl-1 picrylhydrazyl assay}

$\mathrm{W}_{\mathrm{RE}}(0.05-0.4 \mathrm{mg} / \mathrm{ml})$ and butylated hydroxytoluene (BHT) $(60-300 \mu \mathrm{M})$ dilutions were prepared in methanol (99.5\% and grade AR). A $50 \mu \mathrm{M}$ DPPH solution was prepared from a stock solution of $0.135 \mathrm{mM}$ DPPH in methanol. $\mathrm{W}_{\mathrm{RE}}$, BHT dilutions and methanol $(1 \mathrm{ml})$ were aliquoted into $15 \mathrm{ml}$ polypropylene tubes, followed by the $50 \mu \mathrm{M}$ DPPH solution $(1 \mathrm{ml})$. Reaction mixtures were vortexed and incubated [room temperature (RT), $30 \mathrm{~min}$ (min)] in the dark. Absorbance of samples was read at $517 \mathrm{~nm}$ using a Varine Cary 50 UV-visible spectrophotometer (McKinley Scientific, New Jersey, US).

\section{Isolation of peripheral blood mononuclear cells}

Buffy coats containing PBMC's were obtained from the South African National Blood Service (2011/09). PBMC's were extracted by differential centrifugation. Buffy coats $(5 \mathrm{ml})$ were layered onto equivolume histopaque-1077 $(5 \mathrm{ml})$ in $15 \mathrm{ml}$ polypropylene tubes and centrifuged (400×g, $21^{\circ} \mathrm{C}$ for $30 \mathrm{~min}$ ). After centrifugation, the PBMC's were transferred to sterile $15 \mathrm{ml}$ polypropylene tubes, phosphate buffered saline (PBS) was added $(0.1 \mathrm{M}, 10 \mathrm{ml})$ and tubes were centrifuged $\left(400 \times \mathrm{g}, 2{ }^{\circ} \mathrm{C}, 15 \mathrm{~min}\right)$. Cell density of isolated PBMC's was adjusted $\left(1 \times 10^{6}\right.$ cells $\left./ \mathrm{ml}\right)$ using the trypan blue exclusion test and cryo-preserved (10\% FCS, $10 \%$ DMSO) using a NELGENE cryo freezing container and stored at $-80^{\circ} \mathrm{C}$.

\section{Tissue culture}

THP-1 cells were grown in the appropriate tissue culture conditions in a $75 \mathrm{~cm}^{3}$ tissue culture flask $\left(37{ }^{\circ} \mathrm{C}, 5 \%\right.$ $\mathrm{CO}_{2}$ ). The growth media comprised of RPMI-1640, FCS $(10 \%)$ and PSF $(2 \%)$. Cells were thawed, seeded into a $75 \mathrm{~cm}^{3}$ tissue culture flask at a concentration of $3 \times 10^{5}$ cells/ml and incubated $\left(37{ }^{\circ} \mathrm{C}, 5 \% \mathrm{CO}_{2}\right)$. THP-1 cells were allowed to grow for 2-3 days before the cells were centrifuged $(162 \times \mathrm{g}, 10 \mathrm{~min})$ and re-suspended in fresh growth media. The number of cells should not exceed $8 \times 10^{5}$ cells $/ \mathrm{ml}$, therefore the cells $/ \mathrm{ml}$ was quantified daily by trypan blue staining. Once the cell count reached $8 \times 10^{5}$ cells $/ \mathrm{ml}$ the THP- 1 cells were split/diluted to $3 \times 10^{5}$ cells $/ \mathrm{ml}$ with media and incubated. Subsequent experiments were conducted once the cell numbers were sufficient.

\section{Cell viability assay}

Cytotoxicity of $\mathrm{W}_{\mathrm{RE}}$ in PBMC's and THP-1 cells was measured using the WST-1 assay (Roche, Johannesburg, SA). PBMC and THP-1 cells (10,000 cells/well, 96-well plate, in triplicate wells) were stimulated with LPS $\left(20 \mu \mathrm{g} / \mathrm{ml}, 37^{\circ} \mathrm{C}\right.$, $\left.5 \% \mathrm{CO}_{2}, 4 \mathrm{~h}\right)$ before exposure to $\mathrm{W}_{\mathrm{RE}}(0.05-0.4 \mathrm{mg} / \mathrm{ml})$ for 24 and $72 \mathrm{~h}\left(37{ }^{\circ} \mathrm{C}, 5 \% \mathrm{CO}_{2}\right)$. Similarly, controls received media. Thereafter, plates were centrifuged $(162 \times \mathrm{g}, 10 \mathrm{~min})$, supernatant removed, cell pellets re-suspended in growth media $(100 \mu \mathrm{l} /$ well $), \mathrm{WST}-1$ reagent $(10 \mu \mathrm{l} /$ well $)$ added and plates incubated $\left(37^{\circ} \mathrm{C}, 5 \%, \mathrm{CO}_{2}, 3 \mathrm{~h}\right)$. Optical density was measured at $450 \mathrm{~nm}$ (620 nm reference wavelength) with a BIO-TEK $\mu$ Quant spectrophotometer (Analytical and Diagnostic Products, SA). This experiment was conducted independently on three occasions.

\section{Stimulation and treatment of cells}

PBMC's and THP- 1 cells $\left(1 \times 10^{5}\right.$ cells $\left./ \mathrm{ml}\right)$ were transferred into 24-well plates and stimulated with LPS $(20 \mu \mathrm{g} / \mathrm{ml}$, $\left.37{ }^{\circ} \mathrm{C}, 5 \% \mathrm{CO}_{2}, 4 \mathrm{~h}\right)$ before exposure to $\mathrm{W}_{\mathrm{RE}}(0.05-0$. $4 \mathrm{mg} / \mathrm{ml})$ for $24 \mathrm{~h}(\mathrm{TNF}-\alpha)$ and $72 \mathrm{~h}$ (IL-1 $\beta$, IL-6, IL10) $\left(37{ }^{\circ} \mathrm{C}, 5 \% \mathrm{CO}_{2}\right)$. After incubation, plates were centrifuged $(162 \times \mathrm{g}, 10 \mathrm{~min})$ and the supernatant collected and stored $\left(-80{ }^{\circ} \mathrm{C}\right)$ for cytokine analysis. Cell pellets were used to conduct the caspase $(-8,-9,-3 / 7)$ activity, as well as ATP and GSH assays. The experiments were conducted independently (twice) for all subsequent assays. 


\section{Quantification of cytokines}

Cytokine levels were estimated using the BD OptEIA ELISA kits (The Scientific Group, SA) and the procedure was followed as per the instruction manual. ELISA plates were coated with capture antibody overnight $(100 \mu \mathrm{l} /$ well, $\left.4{ }^{\circ} \mathrm{C}\right)$. Thereafter, plates were washed $(3 \times)$ with wash buffer and blocked with assay diluent $(200 \mu \mathrm{l} /$ well, $1 \mathrm{~h}, \mathrm{RT})$. Standard solutions were prepared by diluting a stock solution [TNF- $\alpha$, IL-10 (500 pg/ml), IL-6 (300 pg/ml) , IL-1 $\beta$ (250 pg/ml)] serially [TNF- $\alpha$, IL-10 (500-7.8 pg/ml), IL-6 (300-4.7 pg/ml), IL-1 $\beta$ (250-3.9 pg/ml)]. Plates were washed $(3 \times)$, standards and samples $(100 \mu \mathrm{l} /$ well $)$ were aliquoted into appropriate wells and plates were incubated ( $2 \mathrm{~h}, \mathrm{RT})$. Plates were washed $(5 \times)$, working detector (100 $\mu \mathrm{l} /$ well) added and plates incubated ( $1 \mathrm{~h}, \mathrm{RT})$. The plates were washed $(7 \times)$, substrate solution $(100 \mu \mathrm{l} /$ well $)$ added and plates were incubated (30 min, RT) in the dark. Finally, stop solution $(50 \mu \mathrm{l} /$ well) was added and the absorbance was read at $450 \mathrm{~nm}(570 \mathrm{~nm}$ reference wavelength) with a Multiskan FC micro-plate reader (Thermo Scientific). Cytokine concentrations were calculated by extrapolation from a standard curve.

\section{The glutathione assay}

The GSH-Glo ${ }^{\mathrm{Tm}}$ assay (Promega, Madison, USA) was performed to measure GSH levels. Standard GSH solutions were prepared by diluting a $5 \mathrm{mM}$ stock solution serially $(1.56-50 \mu \mathrm{M})$ and PBS $(0.1 \mathrm{M})$ was the standard blank. Cells $\left(50 \mu \mathrm{l} /\right.$ well, $2 \times 10^{5}$ cells $\left./ \mathrm{ml}\right)$ and standards were added into an opaque 96-well plate, followed by GSHGlo $^{\text {TM }}$ reagent $(25 \mu \mathrm{l} /$ well) and allowed to incubate $(30 \mathrm{~min}$, $\mathrm{RT})$ in the dark. Luciferin detection reagent $(50 \mu \mathrm{l} /$ well $)$ was subsequently added and plates incubated (15 min, RT) in the dark. The absorbance was read on a Modulus ${ }^{\text {TM }}$ microplate luminometer (Turner Biosystems, Sunnyvale, USA) and GSH concentrations were calculated by extrapolation from a standard curve.

\section{Caspase and ATP assays}

Caspase activity and ATP levels were determined using the Caspase-Glo $-3 / 7,-8,-9$ and ATP assay kits (Promega, Madison, USA). Caspase-Glo $-3 / 7,-8,-9$ and ATP reagents were reconstituted according to the manufacturer's instructions. Cells $\left(100 \mu \mathrm{l}, 2 \times 10^{5}\right.$ cells $\left./ \mathrm{ml}\right)$ were added into duplicate wells of a microtitre plate for each assay, thereafter caspase $-3 / 7,-8,-9$ and ATP reagents $(100 \mu \mathrm{l} /$ well) were added into appropriate wells. The plate was incubated (30 min, RT) in the dark. Luminescence was measured on a Modulus ${ }^{\text {TM }}$ microplate luminometer (Turner BioSystems) and expressed as relative light units (RLU).

\section{Statistical analysis}

Statistical analysis was performed using the STATA and GraphPad Prism statistical analysis software. The one- way analysis of variance (ANOVA) was used to compare between groups, followed by the Tukey multiple comparisons test, with $p<0.05$ defining statistical significance.

\section{Results}

The oxidant scavenging potential of $\mathrm{W}_{\mathrm{RE}}$

The oxidant scavenging activity of $\mathrm{W}_{\mathrm{RE}}$ using the $\mathrm{DPPH}$ assay is shown in Fig. $1 . \mathrm{W}_{\mathrm{RE}}(0.05-0.4 \mathrm{mg} / \mathrm{ml})$ significantly increased DPPH scavenging activity by $13.33-46$. $38 \%$ (Fig. 1, $p<0.0001$ ).

\section{The in vitro cytotoxicity of $\mathrm{W}_{\mathrm{RE}}$}

The WST-1 assay was used to determine cell viability of THP-1 cells and PBMC's after treatment with $\mathrm{W}_{\mathrm{RE}}$ (Fig. 2). At $24 \mathrm{~h}, \mathrm{~W}_{\mathrm{RE}}(0.05-0.4 \mathrm{mg} / \mathrm{ml})$ decreased PBMC viability by 20.69-25.15\% while $\mathrm{W}_{\mathrm{RE}}(0.2-0.4 \mathrm{mg} / \mathrm{ml})$ increased THP-1 viability by $15.99-22.54 \%$ as compared to the controls (Fig. 2a and c, $p<0.001$ ). This result suggests that PBMC's are more sensitive to $\mathrm{W}_{\mathrm{RE}}$ treatment than THP-1 cells.

At $72 \mathrm{~h}, \mathrm{PBMC}$ viability was increased (27.16-38.58\%) by $\mathrm{W}_{\mathrm{RE}}(0.05,0.4 \mathrm{mg} / \mathrm{ml})$, as compared to the control (Fig. $2 \mathrm{~b}, p<0.0001)$. In the same time period, $\mathrm{W}_{\mathrm{RE}}(0$. 05-0.4 $\mathrm{mg} / \mathrm{ml}$ ) decreased THP-1 viability by $9.07-16$. $09 \%$ relative to the control (Fig. $2 \mathrm{~d}, p=0.0002$ ).

\section{The immune suppressive properties of $\mathrm{W}_{\mathrm{RE}}$}

$\mathrm{W}_{\mathrm{RE}}$ altered cytokine levels in PBMC's and THP-1 cells (Fig. 3 and Fig. 4). The levels of TNF- $\alpha$, IL-1 $\beta$, IL- 6 and IL-10 produced by LPS stimulated PBMC's was 336.218, 168.100, 657.878 and $46.990 \mathrm{pg} / \mathrm{ml}$ respectively. $\mathrm{W}_{\mathrm{RE}}(0.2-0.4 \mathrm{mg} /$ $\mathrm{ml})$ decreased PBMC TNF- $\alpha$ and IL-10 levels as compared to the control (Fig. 3a and d, $p<0.0001$ ). In PBMC's, IL-6 levels were decreased by $0.4 \mathrm{mg} / \mathrm{ml}$ $\mathrm{W}_{\mathrm{RE}}$, whereas IL-1 $\beta$ levels were increased by $0.05-0$. $4 \mathrm{mg} / \mathrm{ml} \mathrm{W} \mathrm{WE}_{\mathrm{RE}}$ relative to the control (Fig. $3 \mathrm{~b}$ and $\mathrm{c}$, $p<0.0001)$.

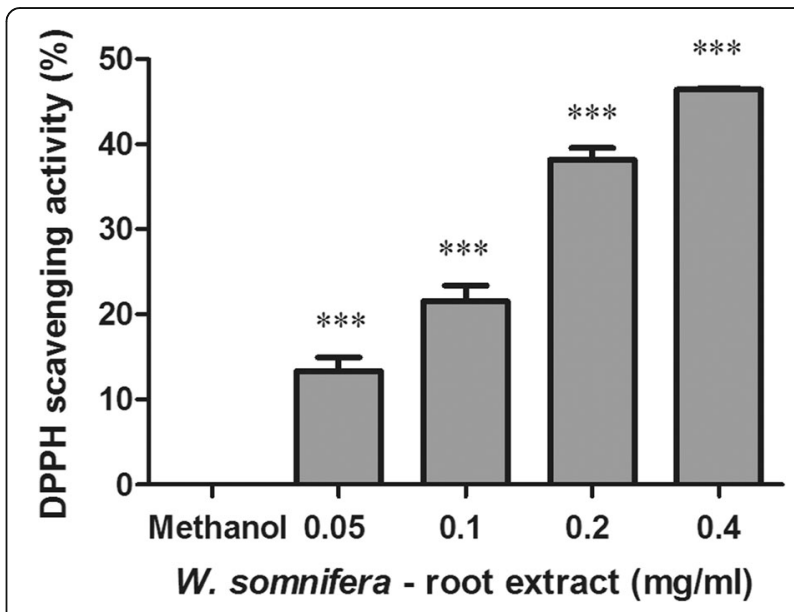

Fig. 1 Percentage DPPH scavenging activity of $W_{R E}$ (Values expressed as mean $\pm \mathrm{SD}^{*}{ }^{*} p<0.05,{ }^{* * *} p<0.0001$, compared to control) 


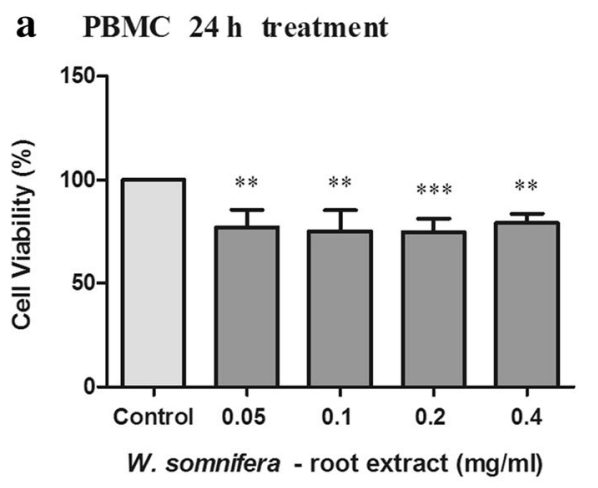

c THP-1 $24 \mathrm{~h}$ treatment

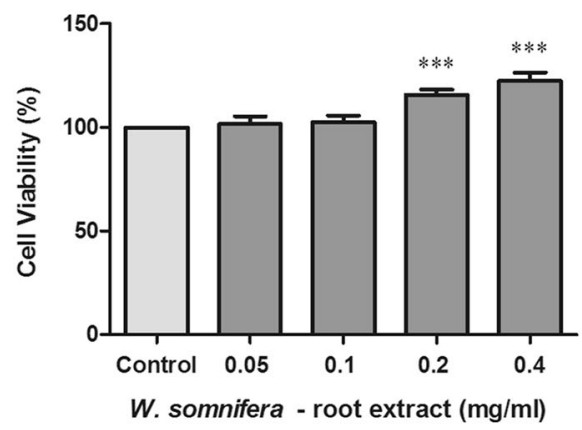

b PBMC $72 \mathrm{~h}$ treatment

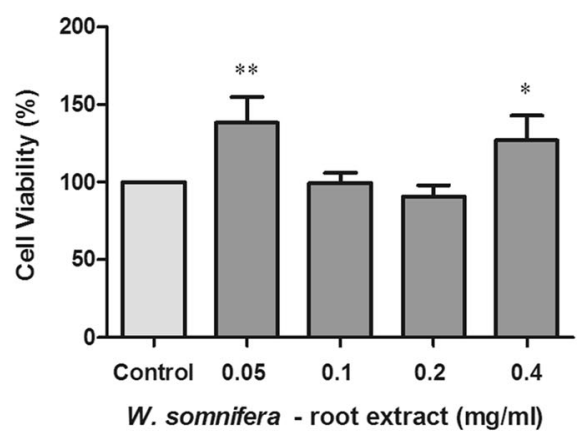

d THP-1 $72 \mathrm{~h}$ treatment

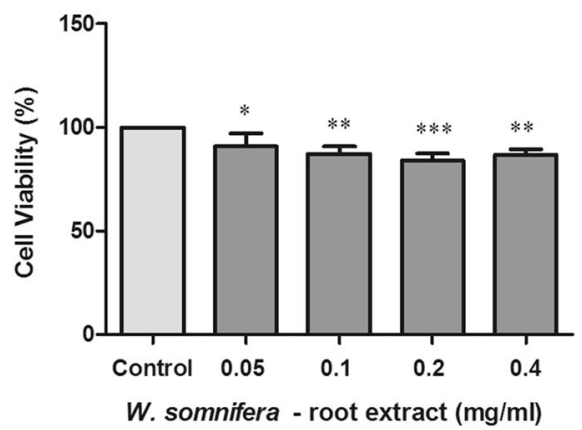

Fig. 2 Cell viability of PBMC's $(\mathbf{a}-24 \mathrm{~h}, \mathbf{b}-72 \mathrm{~h})$ and THP-1 (c- $24 \mathrm{~h}, \mathbf{d}-72 \mathrm{~h})$ cells treated with $\mathrm{W}_{\mathrm{RE}}$ for 24 and $72 \mathrm{~h}$ (Values expressed as mean $\pm \mathrm{SD},{ }^{*} p<0.05, \quad p<0.005,{ }^{* * *} p<0.0001$ compared to the control)

The levels of TNF- $\alpha$, IL-1 $\beta$, IL- 6 and IL-10 produced by LPS stimulated THP-1 cells were 13.285, 21.947, 78.622 and $2.705 \mathrm{pg} / \mathrm{ml}$ respectively. In THP-1 cells, TNF- $\alpha$, IL$1 \beta$ and IL-6 levels were decreased by $0.05-0.4 \mathrm{mg} / \mathrm{ml}$ $\mathrm{W}_{\mathrm{RE}}$, whilst IL-10 levels were decreased by $0.4 \mathrm{mg} / \mathrm{ml}$ $\mathrm{W}_{\mathrm{RE}}$ as compared to the control (Fig. $4, p<0.003$ ).

\section{The antioxidant potential of $\mathrm{W}_{\mathrm{RE}}$}

The endogenous antioxidant activity of $\mathrm{W}_{\mathrm{RE}}$ was determined by measuring GSH levels in both cell lines (Table 1). At $24 \mathrm{~h}, \mathrm{GSH}$ levels in PBMC's were decreased by $\mathrm{W}_{\mathrm{RE}}(0.05,0.2,0.4 \mathrm{mg} / \mathrm{ml})$ relative to the control (Table $1, p<0.0001$ ). In THP-1 cells, GSH levels were decreased at $0.05 \mathrm{mg} / \mathrm{ml} \mathrm{W}_{\mathrm{RE}}$ whereas increased $(0.41-$ $1.62 \mu \mathrm{M})$ at $0.1-0.4 \mathrm{mg} / \mathrm{ml} \mathrm{W} \mathrm{WE}_{\mathrm{RE}}$ compared to the control (Tables 1, 24 h, $p<0.0001$ ).

At $72 \mathrm{~h}$, PBMC GSH levels were increased at $0.05 \mathrm{mg} / \mathrm{ml}$ whereas decreased $0.1-0.4 \mathrm{mg} / \mathrm{ml} \mathrm{W} \mathrm{W}_{\mathrm{RE}}$ compared to the control (Table $1, p<0.0001)$. $\mathrm{W}_{\mathrm{RE}}(0.05-0.4 \mathrm{mg} / \mathrm{ml}) \mathrm{de}-$ creased GSH levels in THP-1 cells relative to the control (Tables $1,72 \mathrm{~h} p<0.0001$ ).

\section{$\mathrm{W}_{\mathrm{RE}}$ modulates caspase $(-8,-9,-3 / 7)$ activities and ATP levels}

Luminometry assays were used to determine caspase activity and ATP levels in THP-1 cells and PBMC's after treatment with $\mathrm{W}_{\mathrm{RE}}$. The pro-apoptotic effect of $\mathrm{W}_{\mathrm{RE}}$ in PBMC's treated for $24 \mathrm{~h}$ is shown in Table 2. At $24 \mathrm{~h}$, PBMC caspase- 8 activity was decreased by $0.05 \mathrm{mg} / \mathrm{ml}$ $\mathrm{W}_{\mathrm{RE}}$ whereas increased by $0.2-0.4 \mathrm{mg} / \mathrm{ml} \mathrm{W}_{\mathrm{RE}}$ compared to the control (Table 2, $p<0.0001$ ). PBMC caspase-9 activity was increased by 0.05 and $0.2 \mathrm{mg} / \mathrm{ml} \mathrm{W}_{\mathrm{RE}}$ but decreased by 0.1 and $0.4 \mathrm{mg} / \mathrm{ml} \mathrm{W} \mathrm{WE}_{\mathrm{RE}}$ relative to the control (Table 2, $p<0.0001$ ). In PBMC's, the increased caspase activity may be related to the decreased GSH levels at $24 \mathrm{~h}$. A decrease in GSH levels may allow for an increase in ROS levels which can activate apoptotic pathways. Caspase-3/7 activity was increased in PBMC's by $0.05-0$. $4 \mathrm{mg} / \mathrm{ml} \mathrm{W} \mathrm{WE}_{\mathrm{RE}}$ compared to the control (Table 2, $p<0$. 0001), suggesting an increased execution of apoptotic cell death. In azoxymethane-induced colon cancer in mice, W. somnifera has been shown to modulate TCA cycle enzymes and the electron transport chain [41]. The PBMC ATP levels were increased by $0.1,0.4 \mathrm{mg} / \mathrm{ml}$ $\mathrm{W}_{\mathrm{RE}}$ but decreased by $0.05,0.2 \mathrm{mg} / \mathrm{ml} \mathrm{W} \mathrm{W}_{\mathrm{RE}}$ compared to the control (Table $2, p<0.0001$ ), which may be related to the modulation of the electron transport chain by W. somnifera.

$\mathrm{W}_{\mathrm{RE}}$ pro-apoptotic effects in THP-1 cells treated for $24 \mathrm{~h}$ are shown in Table 3. At $24 \mathrm{~h}$, THP- 1 caspase- 9 activity was decreased by $0.2 \mathrm{mg} / \mathrm{ml} \mathrm{W} \mathrm{RE}_{\mathrm{RE}}$ but increased by 0 . 05, 0.1, 0.4 $\mathrm{mg} / \mathrm{ml} \mathrm{W} \mathrm{RE}_{\mathrm{R}}$ compared to the control (Table 3, 


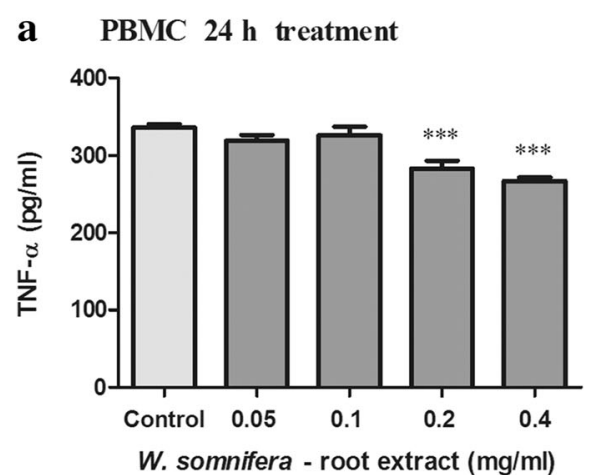

c PBMC $72 \mathrm{~h}$ treatment

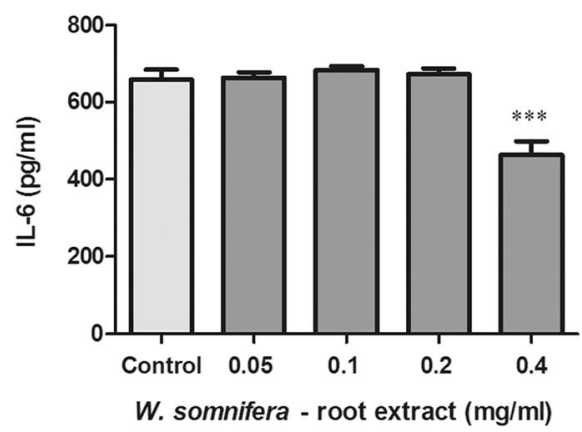

b PBMC $72 \mathrm{~h}$ treatment

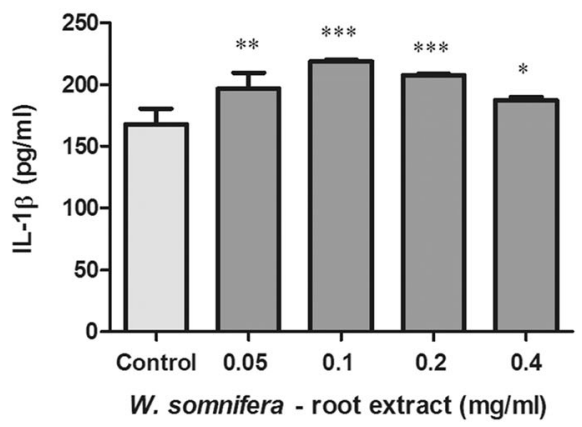

d PBMC $72 \mathrm{~h}$ treatment

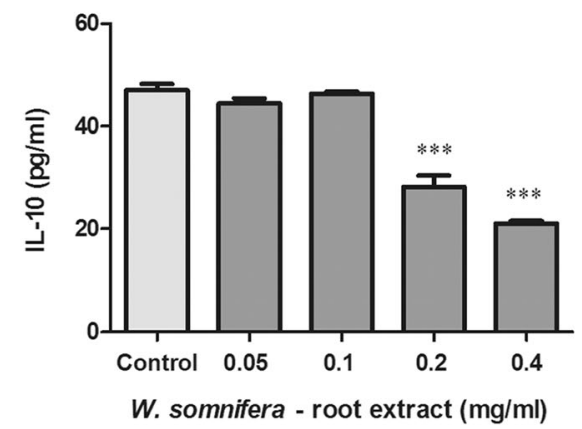

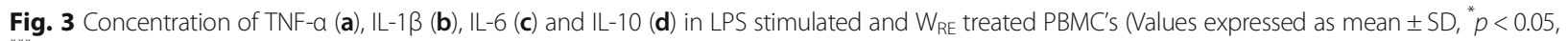
$p<0.0001$, compared to the control)

$p<0.0001$ ). At $0.2 \mathrm{mg} / \mathrm{ml} \mathrm{W}_{\mathrm{RE}}$, the decreased caspase-9 activity may be related to the increased GSH levels. An increase in GSH levels may decrease ROS levels thus minimising mitochondrial depolarisation and the activation of the intrinsic apoptotic pathway. In THP-1 cells, $\mathrm{W}_{\mathrm{RE}}$ $(0.05-0.4 \mathrm{mg} / \mathrm{ml})$ decreased caspase- 8 activity, whereas increased caspase-3/7 activity and ATP levels relative to the control (Table 3, $p<0.0001$ ). Elevated caspase $(-9$, $-3 / 7$ ) activities suggests the initiation of the mitochondrial apoptotic pathway.

The pro-apoptotic effect of $\mathrm{W}_{\mathrm{RE}}$ in PBMC's treated for $72 \mathrm{~h}$ is shown in Table 4. At $72 \mathrm{~h}$, PBMC caspase- 8 activity was increased by $0.05-0.2 \mathrm{mg} / \mathrm{ml} \mathrm{W}_{\mathrm{RE}}$ but decreased by $0.4 \mathrm{mg} / \mathrm{ml} \mathrm{W} \mathrm{WE}_{\mathrm{RE}}$ compared to the control (Table $4, p<0.0001)$. PBMC caspase-9 activity was increased by $0.05-0.1 \mathrm{mg} / \mathrm{ml} \mathrm{W}$ RE but decreased by $0.2-0$. $4 \mathrm{mg} / \mathrm{ml} \mathrm{W} \mathrm{RE}_{\mathrm{RE}}$ relative to the control (Table $4, p<0$. 0001). In PBMC's, caspase-3/7 activity was increased by $0.05,0.1,0.4 \mathrm{mg} / \mathrm{ml} \mathrm{W} \mathrm{RE}_{\mathrm{RE}}$ whereas it decreased by 0 . $2 \mathrm{mg} / \mathrm{ml} \mathrm{W} \mathrm{RE}_{\mathrm{RE}}$ compared to the control (Table 4, $p<0$. 0001). At $0.05-0.1 \mathrm{mg} / \mathrm{ml} \mathrm{W}_{\mathrm{RE}}$, the increased caspase-3/ 7 activity is consistent with the significantly increased caspase -8 and -9 activity. At $0.2 \mathrm{mg} / \mathrm{ml} \mathrm{W}_{\mathrm{RE}}$, caspase- 8 activity was minimally increased and caspase- 9 activity significantly decreased which lead to the decreased caspase- $3 / 7$ activity. At $0.4 \mathrm{mg} / \mathrm{ml} \mathrm{W} \mathrm{WE}_{\mathrm{RE}}$, although both caspase -8 and -9 activities were decreased, caspase- $3 / 7$ activity was increased. A previous study has demonstrated that one activated executioner caspase can cleave and activate other executioner caspases resulting in positive feedback loop of caspase activation [42] which may account for the increased caspase-3/7 activity at $0.4 \mathrm{mg} / \mathrm{ml} \mathrm{W}$ RE. $W_{\text {RE }}(0.05-0$. $4 \mathrm{mg} / \mathrm{ml}$ ) decreased PBMC ATP levels relative to the control (Table $4, p<0.0001$ ).

$\mathrm{W}_{\mathrm{RE}}$ pro-apoptotic effects in THP-1 cells treated for $72 \mathrm{~h}$ are shown in Table 5 . At $72 \mathrm{~h}, \mathrm{THP}-1$ caspase $(-8,-9$, $-3 / 7$ ) activity and ATP levels were increased by $0.1-0$. $2 \mathrm{mg} / \mathrm{ml} \mathrm{W} \mathrm{RE}_{\mathrm{R}}$ as compared to the control (Table 5, $p<0$. 0001), suggesting an increase in THP-1 apoptotic cell death. THP-1 caspase $(-8,-9,-3 / 7)$ activity and ATP levels were decreased by $0.05,0.4 \mathrm{mg} / \mathrm{ml} \mathrm{W}_{\mathrm{RE}}$ relative to the control (Table 5, $72 \mathrm{~h}, p<0.0001$ ), suggesting a decrease in THP-1 apoptosis.

\section{Discussion}

Cachexia patients experience excessive weight loss due to increased lipolysis and proteolysis which have been linked to elevated levels of pro-inflammatory cytokines, 
a THP-1 $24 \mathrm{~h}$ treatment

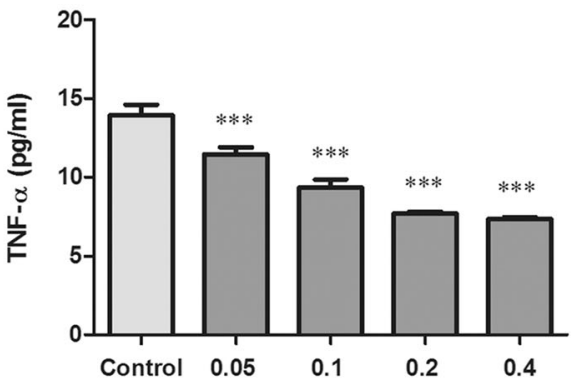

W. somnifera - root extract $(\mathrm{mg} / \mathrm{ml})$

c THP-1 $72 \mathrm{~h}$ treatment

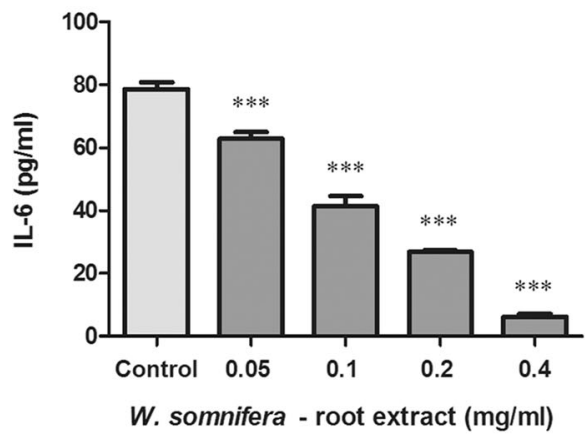

b THP-1 $72 \mathrm{~h}$ treatment

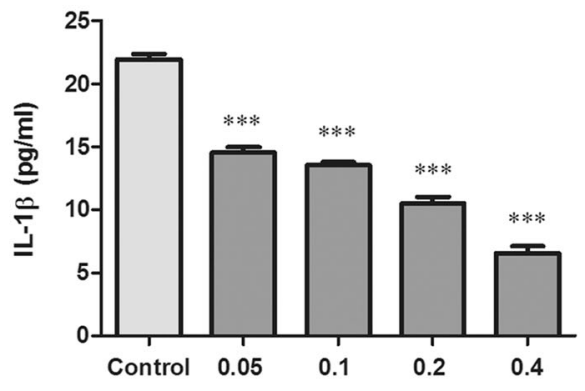

W. somnifera - root extract $(\mathrm{mg} / \mathrm{ml})$

d THP-1 $72 \mathrm{~h}$ treatment

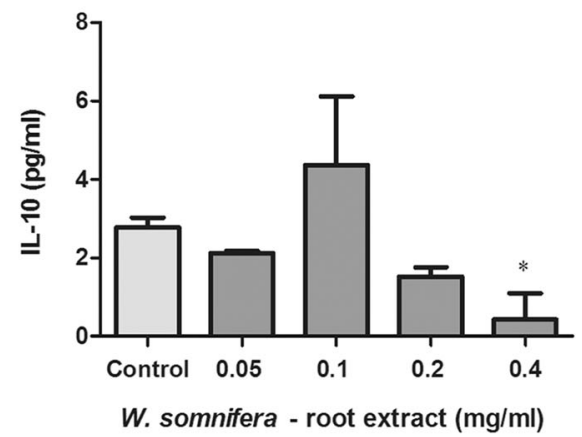

Fig. 4 Concentration of TNF- $a(\mathbf{a}), I L-1 \beta$ (b), IL-6 (c) and IL-10 (d) in LPS stimulated and WRE treated THP-1 cells (Values expressed as mean \pm SD, ${ }^{*} p<0.05,{ }^{* * *} p<0.0001$ compared to the control)

oxidative stress and apoptosis [3, 5, 30]. Previously, the powdered root of $W$. somnifera displayed immune modulatory properties [43] and WSF has been shown to increase caspase- 3 activity, subsequently inducing apoptosis [38]. The objective of this study was thus to investigate the modulation of cytokines, antioxidants and cell death by $\mathrm{W}_{\mathrm{RE}}$ in PBMC's and THP-1 cells.

Dhanani et al. (2017) showed that the root extract of W. somnifera inhibited $50 \%$ of DPPH at a concentration of $0.4 \mathrm{mg} / \mathrm{ml}$ [44]. Our results indicated that $\mathrm{W}_{\mathrm{RE}}$ has oxidant scavenging potential ranging between 13 and $46 \%$ at $0.05-0.4 \mathrm{mg} / \mathrm{ml}$. ROS plays an essential role in tumour initiation, inflammation, protein degradation and apoptosis. The antioxidant potential of $\mathrm{W}_{\mathrm{RE}}$ may decrease inflammatory cytokine levels as well as ROS induced apoptosis.

At $24 \mathrm{~h}$, the WST-1 results indicated that $\mathrm{W}_{\mathrm{RE}}$ decreased PBMC viability whilst increasing THP-1 viability. However at $72 \mathrm{~h}, \mathrm{~W}_{\mathrm{RE}}$ increased PBMC viability whilst conversely decreasing THP-1 viability. In contrast, the growth of various cell lines (HT-29, HCT-15, SW620, 502,713, Colo-205, A549, HOP-62 and Hep-G2) were dose dependently inhibited by WSF and 50\% cell growth inhibition was seen at $30 \mu \mathrm{g} / \mathrm{ml} \mathrm{WSF} \mathrm{[38].}$

Table 1 Glutathione levels in LPS stimulated and WRE treated PBMC's and THP-1 cells

\begin{tabular}{|c|c|c|c|c|}
\hline \multicolumn{5}{|c|}{ Glutathione $(\mu \mathrm{M})$} \\
\hline \multirow[t]{2}{*}{$W_{\mathrm{RE}}(\mathrm{mg} / \mathrm{ml})$} & \multicolumn{2}{|l|}{$24 \mathrm{~h}$ Treatment } & \multicolumn{2}{|l|}{$72 \mathrm{~h}$ Treatment } \\
\hline & PBMC & THP-1 & PBMC & THP-1 \\
\hline Control & $1.613 \pm 0.017$ & $1.632 \pm 0.004$ & $4.799 \pm 0.008$ & $1.608 \pm 0.004$ \\
\hline 0.05 & $1.442 \pm 0.024^{* * *}$ & $1.267 \pm 0.004^{* * *}$ & $5.232 \pm 0.011^{* * *}$ & $1.548 \pm 0.002$ \\
\hline 0.1 & $1.617 \pm 0.002$ & $2.045 \pm 0.002^{* * *}$ & $4.015 \pm 0.001^{* * *}$ & $1.589 \pm 0.004^{* * *}$ \\
\hline 0.2 & $1.390 \pm 0.001^{* * *}$ & $3.253 \pm 0.017^{* * *}$ & $2.323 \pm 0.005^{* * *}$ & $1.401 \pm 0.006^{* * *}$ \\
\hline 0.4 & $1.321 \pm 0.006^{* * *}$ & $2.785 \pm 0.005^{* * *}$ & $4.697 \pm 0.003^{* * *}$ & $1.411 \pm 0.005^{* * *}$ \\
\hline
\end{tabular}

(Values expressed as mean $\pm \mathrm{SD}^{* * *} p<0.0001$, compared to the control) 
Table 2 Modulation of caspase $(-8,-9,-3 / 7)$ activity and ATP levels in LPS stimulated and $24 \mathrm{~h} \mathrm{~W}_{\mathrm{RE}}$ treated PBMC's

\begin{tabular}{lllll}
\hline$W_{\text {RE }}(\mathrm{mg} / \mathrm{ml})$ & Caspase-8 $\left(\mathrm{RLU} \times 10^{5}\right)$ & Caspase-9 $\left(\mathrm{RLU} \times 10^{5}\right)$ & Caspase-3/7 (RLU $\left.\times 10^{5}\right)$ & ATP $\left(\mathrm{RLU} \times 10^{5}\right)$ \\
\hline Control & $0.185 \pm 0.006$ & $0.366 \pm 0.0003$ & $7.756 \pm 0.006$ & $4.714 \pm 0.004$ \\
0.05 & $0.155 \pm 0.0002^{* * *}$ & $0.376 \pm 0.001^{* * *}$ & $8.109 \pm 0.094^{* *}$ & $2.783 \pm 0.017^{* * *}$ \\
0.1 & $0.192 \pm 0.00002^{* * * *}$ & $0.253 \pm 0.0002^{* * *}$ & $11.504 \pm 0.253^{* * *}$ & $5.208 \pm 0.005^{* * *}$ \\
0.2 & $0.246 \pm 0.0003^{* * *}$ & $0.397 \pm 0.0005^{* * *}$ & $8.961 \pm 0.015^{* * *}$ & $3.741 \pm 0.033^{* * *}$ \\
0.4 & $4.814 \pm 0.006^{* * *}$ & $0.351 \pm 0.001^{* * *}$ & $17.095 \pm 0.089^{* * *}$ & $6.965 \pm 0.039^{* * *}$ \\
\hline
\end{tabular}

(Values expressed as mean $\pm \mathrm{SD}^{* * *} p<0.005,{ }^{* * *} p<0.0001$ compared to the control)

The pivotal role of inflammatory cytokines in malignancies and cachexia has been extensively documented [3]. Dhuley (1997) previously reported that W. somnifera inhibits macrophage production of inflammatory cytokines (IL-1, TNF- $\alpha$ ) [45]. Our results showed that $\mathrm{W}_{\mathrm{RE}}$ decreased PBMC TNF- $\alpha$, IL-10 and IL- 6 levels, although it increased IL-1 $\beta$ levels. In THP-1 cells, pro-inflammatory cytokine (TNF- $\alpha$, IL-1 $\beta$, IL-6) levels were significantly decreased by $W_{\mathrm{RE}}$.

Pro-inflammatory cytokines, over a longstanding time period, stimulate the production of genotoxic molecules [nitric oxide (NO), ROS] and tumour progression by promoting angiogenesis and metastasis $[1,2]$. In addition, pro-inflammatory cytokines activate NF- $\mathrm{B}$ which regulates the expression of genes involved in the suppression of tumour apoptosis, stimulation of tumour cell cycle progression and enhancement of inflammatory mediators $[1,2]$. NF- $\mathrm{kB}$ promotes tumour progression, invasion, angiogenesis and metastasis $[1,2]$.

Previous literature has shown that IL-1 stimulates growth and invasion of malignant cells [2]. Additionally, IL-6 has been shown to target cell cycle progression and anti-apoptotic genes leading to tumour proliferation and anti-apoptotic potential [2]. The ability of $\mathrm{W}_{\mathrm{RE}}$ to increase pro-inflammatory cytokines such as IL-1 $\beta$ in PBMC's may aid in cancerous cell elimination through increased host anti-tumour activity. Conversely, in THP1 cells, the decrease in TNF- $\alpha$, IL- 6 and IL- $1 \beta$ levels by $\mathrm{W}_{\mathrm{RE}}$ may prevent excessive activation of NF- $\mathrm{kB}$, diminish cytokine induced tumour immunosuppressive activity and cancer progression.
With regard to cancer cachexia, IL-6 decreased LPL activity in adipose tissue of mice [22] and IL-1 directly modulates lipid metabolism by suppressing LPL activity [23]. TNF- $\alpha$ decreased LPL activity in adipose tissue of human (maintained in organ culture), rat, mouse, and guinea pigs [21]. Additionally, TNF- $\alpha$ inhibits the production of LPL and reduces the rate of LPL gene transcription in mouse 3 T3-L1 adipocytes, hence preventing the formation of new lipid stores while stimulating HSL and increasing lipolysis $[3,20,46]$. The potential of $\mathrm{W}_{\mathrm{RE}}$ to decrease proinflammatory cytokine levels in PBMC's and THP-1 cells suggests a decrease in LPL inhibition and HSL stimulation, thus maintaining lipogenesis and minimizing lipolysis. IL-6 and TNF- $\alpha$ further contribute to cachexia by stimulating muscle catabolism via the activation of proteasome pathways [24, 25, 47]. In cachexia, NF-кB activation induces ubiquitin-proteasome pathway activity and suppresses MyoD expression [48], thereby increasing proteolysis and reducing muscle replenishment [49]. By decreasing TNF- $\alpha$ and IL- 6 levels in PBMC's and THP-1 cells, $W_{R E}$ may prevent excessive activation of NF- $\mathrm{kB}$ and proteasome pathways, ultimately decreasing proteolysis associated with the cachectic syndrome. Taken together, $\mathrm{W}_{\mathrm{RE}}$ may be able to decrease tissue wasting through the down regulation of pro-inflammatory cytokine levels.

The immunosuppressive and anti-inflammatory cytokine, IL-10, inhibits tumour development, tumour progression, modulates apoptosis and suppresses angiogenesis during tumour regression $[1,2]$. Additionally, IL-10 inhibits NF- $\mathrm{B}$ activation and subsequently inhibits pro-inflammatory cytokine production (TNF- $\alpha$, and IL-6) [2]. In PBMC's and

Table 3 Modulation of caspase $(-8,-9,-3 / 7)$ activity and ATP levels in LPS stimulated and $24 \mathrm{~h} \mathrm{~W}_{\mathrm{RE}}$ treated THP-1 cells

\begin{tabular}{lllll}
\hline$W_{\text {RE }}(\mathrm{mg} / \mathrm{ml})$ & Caspase-8 $\left(\mathrm{RLU} \times 10^{5}\right)$ & Caspase-9 $\left(\mathrm{RLU} \times 10^{5}\right)$ & Caspase-3/7 (RLU $\left.\times 10^{5}\right)$ & ATP $\left(\mathrm{RLU} \times 10^{5}\right)$ \\
\hline Control & $10.207 \pm 0.011$ & $1.040 \pm 0.007$ & $1.251 \pm 0.016$ & $2.636 \pm 0.011$ \\
0.05 & $8.440 \pm 0.039^{* * *}$ & $2.365 \pm 0.005^{* * *}$ & $1.315 \pm 0.005^{* * *}$ & $3.726 \pm 0.005^{* * *}$ \\
0.1 & $2.413 \pm 0.005^{* * *}$ & $2.459 \pm 0.002^{* * *}$ & $2.294 \pm 0.006^{* * *}$ & $5.132 \pm 0.014^{* * *}$ \\
0.2 & $7.149 \pm 0.027^{* * *}$ & $0.775 \pm 0.002^{* * *}$ & $3.406 \pm 0.006^{* * *}$ & $29.838 \pm 0.186^{* * *}$ \\
0.4 & $2.456 \pm 0.033^{* * *}$ & $3.197 \pm 0.0001^{* * *}$ & $9.428 \pm 0.004^{* * *}$ & $10.282 \pm 0.195^{* * *}$ \\
\hline
\end{tabular}

(Values expressed as mean $\pm \mathrm{SD},{ }^{* * *} p<0.0001$ compared to the control) 
Table 4 Modulation of caspase $(-8,-9,-3 / 7)$ activity and ATP levels in LPS stimulated and $72 \mathrm{~h} \mathrm{~W}_{\mathrm{RE}}$ treated PBMC's

\begin{tabular}{lllll}
\hline$W_{\text {RE }}(\mathrm{mg} / \mathrm{ml})$ & Caspase-8 $\left(\mathrm{RLU} \times 10^{5}\right)$ & Caspase-9 $\left(\mathrm{RLU} \times 10^{5}\right)$ & Caspase-3/7 (RLU $\left.\times 10^{5}\right)$ & ATP (RLU $\left.\times 10^{5}\right)$ \\
\hline Control & $42.651 \pm 0.039$ & $115.041 \pm 3.848$ & $155.556 \pm 0.387$ & $20.574 \pm 0.316$ \\
0.05 & $53.840 \pm 0.026^{* * *}$ & $143.861 \pm 3.929^{* * *}$ & $196.471 \pm 0.338^{* * *}$ & $10.223 \pm 0.046^{* * *}$ \\
0.1 & $52.109 \pm 0.009^{* * *}$ & $129.033 \pm 0.289^{* * *}$ & $192.695 \pm 0.233^{* * *}$ & $12.506 \pm 0.373^{* * *}$ \\
0.2 & $42.751 \pm 0.039^{* *}$ & $105.494 \pm 4.247^{* *}$ & $154.203 \pm 0.224^{* * *}$ & $13.210 \pm 0.043^{* * *}$ \\
0.4 & $29.656 \pm 0.007^{* * *}$ & $92.718 \pm 0.021^{* * *}$ & $165.139 \pm 0.096^{* * *}$ & $13.361 \pm 0.279^{* * *}$ \\
\hline
\end{tabular}

(Values expressed as mean $\pm \mathrm{SD}^{* *} p<0.005,{ }^{* * *} p<0.0001$ compared to the control)

THP-1 cells, the decreased IL-10 levels may be due to IL10 combating increased pro-inflammatory cytokines levels (TNF- $\alpha$, IL-6, IL-1 $\beta$ ).

Antioxidants protect cells from increased oxidative stress [50]. GSH is a potent antioxidant that effectively scavenges ROS both directly and indirectly [50]. W. somnifera has previously been shown to possess chemo-preventive activity which may be a consequence of its antioxidant capacity [39]. The $24 \mathrm{~h}$ results showed that $\mathrm{W}_{\mathrm{RE}}$ decreased GSH levels in PBMC's, whereas it increased GSH levels in THP1 cells. However, at $72 \mathrm{~h}, \mathrm{~W}_{\mathrm{RE}}$ decreased GSH levels in both cell lines. Notably, GSH levels $(72 \mathrm{~h})$ were higher in control PBMC's $(4.79 \mu \mathrm{M})$ compared to control THP-1 cells $(1.61 \mu \mathrm{M})$, suggesting a higher oxidant defence in PBMC's.

The extrinsic (death receptors) and intrinsic (mitochondria) pathways are the two main apoptotic pathways [29]. Activation of initiator caspases $(-8,-9)$ leads to the activation of executioner caspases $(-3 / 7)$ resulting in activation of cytoplasmic endonucleases [29]. In HL-60 cells, WSF treatment led to a loss of mitochondrial membrane potential, translocation of Bax to mitochondria, release of cytochrome c, Smac/DIABLO and apoptosis inducing factor, suggesting the activation of the intrinsic apoptotic pathway [38]. Additionally, WSF treated HL-60 cells showed an over-expression of TNF receptor- 1 and death receptor- 4 with associated caspase8 activation, suggesting the activation of the extrinsic apoptotic pathway [38]. Our $24 \mathrm{~h}$ results showed that $\mathrm{W}_{\mathrm{RE}}$ increased PBMC caspase $-8,-9$ and $-3 / 7$ activities at different concentrations, suggesting the activation of extrinsic and intrinsic apoptotic pathways. In the same time period, $\mathrm{W}_{\mathrm{RE}}$ increased THP-1 caspase -9 and $-3 / 7$ activities, suggesting initiation of apoptosis through the intrinsic pathway. At $72 \mathrm{~h}, \mathrm{~W}_{\mathrm{RE}}(0.05-0.1 \mathrm{mg} / \mathrm{ml})$ increased caspase $(-8,-9,-3 / 7)$ activities, suggesting an increased initiation of PBMC apoptotic cell death. However, $0.4 \mathrm{mg} / \mathrm{ml} \mathrm{W} \mathrm{RE}_{\mathrm{RE}}$ decreased initiator caspase $(-8$, -9) activities, suggesting a decreased initiation of PBMC apoptotic cell death. In THP-1 cells, $0.1-0.2 \mathrm{mg} / \mathrm{ml} \mathrm{W} \mathrm{WE}_{\mathrm{RE}}$ $(72 \mathrm{~h})$ increased caspase $(-8,-9,-3 / 7)$ activities, suggesting initiation of apoptosis through the intrinsic and extrinsic pathways. However, at 0.05 and $0.4 \mathrm{mg} / \mathrm{ml} \mathrm{W} \mathrm{W}_{\mathrm{RE}}$ (72 h), THP-1 caspase $(-8,-9,-3 / 7)$ activities were decreased, suggesting a decrease in THP-1 apoptosis. Previous studies have indicated that $W$. somnifera may activate the extrinsic and intrinsic apoptotic pathways [38], therefore our results prove to be consistent with other studies.

Increased caspase- 3 activity, proteasome activity and E3 ubiquitin-conjugating enzyme expression is associated with increased proteolysis [51]. Therefore the ability of $W_{R E}(0.4 \mathrm{mg} / \mathrm{ml}, 72 \mathrm{~h})$ to down regulate caspase activity in PBMC's and THP-1 cells may decrease proteolysis and the progression of cancer cachexia.

A successful anti-cancer drug should kill or incapacitate cancer cells without causing excessive damage to normal cells [39]. The potential of $\mathrm{W}_{\mathrm{RE}}$ to regulate PBMC apoptosis while increasing cancerous THP-1 cell apoptosis may be beneficial to cancer patients by preventing excessive cancerous cell growth while minimally effecting healthy PBMC's.

Table 5 Modulation of caspase $(-8,-9,-3 / 7)$ activity and ATP levels in LPS-stimulated and 72 h W RE$^{-t r e a t e d ~ T H P-1 ~ c e l l s ~}$

\begin{tabular}{|c|c|c|c|c|}
\hline$W_{R E}(\mathrm{mg} / \mathrm{ml})$ & Caspase-8 $\left(\mathrm{RLU} \times 10^{5}\right)$ & Caspase-9 $\left(\mathrm{RLU} \times 10^{5}\right)$ & Caspase-3/7 (RLU $\left.\times 10^{5}\right)$ & ATP $\left(\right.$ RLU $\left.\times 10^{5}\right)$ \\
\hline Control & $0.991 \pm 0.0001$ & $5.738 \pm 0.002$ & $7.463 \pm 0.012$ & $4.332 \pm 0.002$ \\
\hline 0.05 & $0.978 \pm 0.0001^{* * *}$ & $5.562 \pm 0.009^{* * *}$ & $6.919 \pm 0.003^{* * *}$ & $4.133 \pm 0.005^{* * *}$ \\
\hline 0.1 & $1.216 \pm 0.001^{* * *}$ & $7.045 \pm 0.005^{* * *}$ & $8.211 \pm 0.002^{* * *}$ & $4.889 \pm 0.005^{* * *}$ \\
\hline 0.2 & $1.095 \pm 0.001^{* * *}$ & $6.091 \pm 0.0011^{* * *}$ & $7.532 \pm 0.006^{* * *}$ & $4.576 \pm 0.004^{* * *}$ \\
\hline 0.4 & $0.952 \pm 0.0003^{* * *}$ & $5.639 \pm 0.003^{* * *}$ & $6.626 \pm 0.007^{* * *}$ & $4.039 \pm 0.0003^{* * *}$ \\
\hline
\end{tabular}

(Values expressed as mean $\pm \mathrm{SD},{ }^{* * *} p<0.0001$ compared to the control) 


\section{Conclusion}

The cachectic syndrome decreases the quality of life of patients, the responsiveness to chemotherapy and leads to $20-25 \%$ of cancer deaths [3]. Our results show that $\mathrm{W}_{\mathrm{RE}}$ increased oxidant scavenging activity, modulated GSH and pro-inflammatory cytokine levels and regulated caspase activity in normal PBMC's and THP-1 cells. The discovery of a medicinal plant capable of decreasing the levels of pro-inflammatory cytokines may decrease tissue wasting. In this study, the root extract of W. somnifera has shown promising results in modulating the production of cytokines associated with cancer cachexia. The ability of $\mathrm{W}_{\mathrm{RE}}$ to decrease pro-inflammatory cytokine levels and increase cancerous cell death may decrease the development and progression of cancer and cachexia. $\mathrm{W}_{\mathrm{RE}}$ may therefore be effective in cancer cachexia.

\section{Additional file}

Additional file 1: Assay data from root extract of $W$. Somnifera. (XLSX $288 \mathrm{~kb}$ )

\section{Abbreviations}

ATP: Adenosine triphosphate; BHT: butylated hydroxytoluene; DNA: Deoxyribonucleic acid; DPPH: 2, 2-diphenyl-1 picrylhydrazyl; ELISA: enzyme-linked immunosorbant assay; FA's: fatty acids; FCS: Foetal calf serum; GSH: Gluthatione; h: Hours; HL-60: Human promyelocytic leukemia; HSL: hormone sensitive lipase; IL: interleukin; LPL: lipoprotein lipase; LPS: lipopolysaccharide; min: Minute; NF-kB: Nuclear factor kappa B; NO: nitric oxide; PARP: poly (ADP-ribose) polymerase; PBMC's: peripheral blood mononuclear cells; PBS: phosphate buffered saline; PSF: Pen/Strep Amphotericin B; RLU: Relative light units; ROS: reactive oxygen species; RT: room temperature; SA: South Africa; TAG: triacylglycerol; THP-1: leukemic cell line; TNF-a: tumour necrosis factor-a; W. somnifera: Withania somnifera; WRE: W. somnifera aqueous root extract; WSF: W. somnifera formulation; WST1: 4-[3-(4-iodophenyl)-2-(4-nitrophenyl)-2H-5-tetrazolio]-1,3-benzene disulfonate

\section{Acknowledgements}

We are grateful to the National Research Foundation, the South African Medical Research Council, Department of Science and Technology, Government of India and Manipal University for financial support to conduct experimentation. The authors also acknowledge Miss Tarylee Reddy for assistance with statistical analysis of data.

\section{Funding}

Sources of funding included the National Research Foundation, the South African Medical Research Council and Department of Science and Technology, Government of India and Manipal University, India. The funding sources were not involved in study design, collection of samples, analysis of data, interpretation of data, writing of the report and decision to publish. Scientific output is a requirement of the National Research Foundation.

\section{Availability of data and materials}

All data generated or analysed during this study are included in this published article as a Additional file 1.

\section{Authors' contributions}

DBN carried out all experimentation except the luminometry (Caspase, ATP GSH) assays. DBN analysed and interpreted data, performed statistical analysis, drafted and revised the manuscript. AC and AP carried out luminometry assays and provided intellectual input into the manuscript. VS, KPG and KS gave substantial contributions to conception, design and supervision of the study and revision of the manuscript. All authors read and approved the final manuscript.

\section{Ethics approval and consent to participate}

Collection of PBMC's was approved by the Ethics Committee of the South African Medical Research Council (EC09-018) and the South African National Blood Service (2011/09).

\section{Consent for publication}

Not applicable.

\section{Competing interests}

The author(s) declare that they have no competing interests.

\section{Publisher's Note}

Springer Nature remains neutral with regard to jurisdictional claims in published maps and institutional affiliations.

\section{Author details}

${ }^{1}$ Discipline of Medical Biochemistry, Faculty of Health Sciences, Nelson Mandela School of Medicine, University of KwaZulu-Natal, Durban 4013, South Africa. ${ }^{2}$ Division of Biotechnology, School of Life Sciences, Manipal University, Planetarium Complex, Manipal, Karnataka 576 104, India. ${ }^{3}$ African Cancer Institute, Stellenbosch University, P.O. Box 241, Cape Town 8000, South Africa. ${ }^{4}$ Department of Global Health, Faculty of Medicine and Health Sciences, Stellenbosch University, P.O. Box 241, Cape Town 8000, South Africa.

Received: 2 June 2017 Accepted: 28 March 2018 Published online: 10 April 2018

\section{References}

1. Landskron G, De la Fuente M, Thuwajit P, Thuwajit C, Hermoso MA. Chronic inflammation and cytokines in the tumor microenvironment. J Immunol Res. 2014; https://doi.org/10.1155/2014/149185.

2. Lin WW, Karin M. A cytokine-mediated link between innate immunity, inflammation, and cancer. J Clin Invest. 2007;117(5):1175-83.

3. Tisdale MJ. Mechanisms of cancer cachexia. Physiol Rev. 2009:89(2):381-410.

4. Tisdale MJ. Loss of skeletal muscle in cancer: biochemical mechanisms. Front Biosci. 2001;6:D164-74

5. Inui A. Cancer anorexia-cachexia syndrome: current issues in research and management. CA Cancer J Clin. 2002;52(2):72-91.

6. Vlassara H, Speigel RJ, San Doval D, Cerami A. Reduced plasma lipoprotien lipase activity in patients with malignancy-associated weight loss. Horm Metab Res. 1986;18(10):698-703.

7. Lanza-Jacoby S, Lansey SC, Miller EE, Cleary MP. Sequential changes in the activities of lipoprotien lipase and lipogenic enzymes during tumor growth in rats. Cancer Res. 1984;44(11):5062-7.

8. Thompson MP, Cooper ST, Parry BR, Tuckey JA. Increased expression of the mRNA for hormone-sensitive lipase in adipose tissue of cancer patients. Biochim Biophys Acta. 1993;1180(3):236-42.

9. Lundholm K, Bennegard K, Eden E, Svaninger G, Emery PW, Rennie MJ. Efflux of 3-methylhistidine from the leg in cancer patients who experience weight loss. Cancer Res. 1982;42(11):4807-11.

10. Lundholm K, Bylund AC, Holm J, Scherstén T. Skeletal muscle metabolism in patients with malignant tumour. Eur J Cancer. 1976;12(6):465-73.

11. Lecker SH, Solomon V, Mitch WE, Goldberg AL. Muscle protein breakdown and critical role of the ubiquitin-proteasome pathway in normal and disease states. J Nutr. 1999;129(Suppl 1):227-37.

12. Anker SD, Chua TP, Ponikowski P, Harrington D, Swan JW, Kox WJ, et al. Hormonal changes and catabolic / anabolic imbalance in chronic heart failure and their importance for cardiac cachexia. Circulation. 1997;96(2): 526-34.

13. Anker SD, Rauchhaus M. Insights into the pathogenesis of chronic heart failure: immune activation and cachexia. Curr Opin Cardiol. 1999;14(3):211-6.

14. Mehta VB, Hart J, Wewers MD. ATP-stimulated release of interleukin (IL)1 beta and IL-18 requires priming by lipopolysaccharide and is independent of caspase-1 cleavage. J Biol Chem. 2001;276(6):3820-6.

15. Van Snick J. Interleukin-6: an overview. Annu Rev Immunol. 1990;8:253-78.

16. Akira S. Toll-like receptor signaling. J Biol Chem. 2003;278(40):38105-8.

17. Janssen-Heininger YM, Poynter ME, Baeuerle PA. Recent advances towards understanding redox mechanisms in the activation of nuclear factor kappaB. Free Radic Biol Med. 2000;28(9):1317-27. 
18. Park HS, Jung HY, Park EY, Kim J, Lee WJ, Bae YS. Cutting edge: direct interaction of TLR4 with NAD(P)H oxidase 4 isozyme is essential for lipopolysaccharide-induced production of reactive oxygen species and activation of NF-kappaB. J Immunol. 2004;173(6):3589-93.

19. Asehnoune K, Strassheim D, Mitra S, Kim JY, Abraham E. Involvement of reactive oxygen species in toll-like receptor 4-dependent activation of NFkappa B. J Immunol. 2004;172(4):2522-9.

20. Cornelius P, Enerback S, Bjursell G, Olivecrona T, Pekala PH. Regulation of lipoprotien lipase mRNA content in 3T3-L1 cells by tumour necrosis factor Biochem J. 1988;249(3):765-9.

21. JM A'e, Busquets S, Felipe A, FJ L'o-S. Molecular mechanisms involved in muscle wasting in cancer and ageing: cachexia versus sarcopenia. Int J Biochem Cell Biol. 2005;37(5):1084-104.

22. Greenberg AS, Nordan RP, McIntosh J, Calvo JC, Scow RO, Jablons D. Interleukin 6 reduces lipoprotien lipase activity in adipose tissue of mice in vivo and in 3T3-L1 adipocytes: a possible role for interleukin 6 in cancer cachexia. Cancer Res. 1992;52(15):4113-6.

23. Beutler BA, Cerami A. Recombinant interleukin 1 suppresses lipoprotein lipase activity in 3T3-L1 cells. J Immunol. 1985;135(6):3969-71.

24. Garcia-Martinez C, Agell N, Llovera M, López-Soriano FJ, Argilés JM. Tumour necrosis factor-alpha increases the ubiquitinization of rat skeletal muscle proteins. FEBS Lett. 1993;323(3):211-4.

25. Garcia-Martinez C, Llovera M, Agell N, López-Soriano FJ, Argilés JM. Ubiquitin gene expession in skeletal muscle is increased during sepsis: involvement of TNF-alpha but not IL-1. Biochem Biophys Res Comm. 1995;217(3):839-44.

26. Ebisui C, Tsujinaka T, Morimoto T, Kan K, lijima S, Yano M, et al. Interleukin-6 induces proteolysis by activating intracellular proteases (cathepsins B and $\mathrm{L}$, proteasome) in C2C12 myotubes. Clin Sci. 1995;89(4):431-9.

27. Grivennikov SI, Greten FR, Karin M. Immunity, inflammation, and Cancer. Cell. 2010;140(6):883-99.

28. Buck $M$, Chojkier M. Muscle wasting and dedifferentiation induced by oxidative stress in a murine model of cachexia is prevented by inhibitors of nitric oxide synthesis and antioxidants. EMBO J. 1996;15(8):1753-65.

29. Elmore S. Apoptosis: a review of programmed cell death. Toxicol Pathol. 2007;35(4):495-516.

30. Du J, Wang X, Miereles C, Bailey JL, Debigare R, Zheng B, et al. Activation of caspase-3 is an initial step triggering accelerated muscle proteolysis in catabolic conditions. J Clin Invest. 2004;113(1):115-23.

31. Singh G, Sharma PK, Dudhe R, Singh S. Biological activities of Withania somnifera. Ann. Biol Res. 2010;1(3):56-63.

32. Budhiraja RD, Krishan P, Sudhir S. Biological activity of withanolides. J Sci Ind Res. 2000;59:904-11.

33. Malik F, Singh J, Khajuria A, Suri KA, Satti NK, Singh S, et al. A standardized root extract of Withania somnifera and its major constituent withanolide-a elicit humoral and cell-mediated immune responses by up regulation of Th1-dominant polarization in BALB/c mice. Life Sci. 2007;80(16):1525-38.

34. Sudhir S, Budhiraja RD, Miglani GP, Arora B, Gupta LC, Garg KN. Pharmacological studies on leaves of Withania somnifera. Planta Med. 1986;1:61-3.

35. Thakur RS, Puri HS, Husain A. Major medicinal plants of India. New Delhi: central Institute of Medicinal and Aromatic. Plants. 1986;

36. Agarwal R, Diwanay S, Patki PS, Patwardhan B. Studies on immunomodulatory activity of Withania somnifera (Ashwagandha) extracts in experimental immune inflammation. J Ethnopharmacol. 1999;67(1):27-35.

37. Kamath R, Satish Rao BS, Uma Devi P. Response of a mouse fibrosarcoma to withferin a and radiation. Pharm Pharmacol Commun. 1999;5(4):287-91.

38. Malik F, Kumar A, Bhushan S, Mondhe DM, Pal HC, Sharma R, et al. Immune modulation and apoptosis induction: two sides of antitumoural activity of a standardized herbal formulation of Withania somnifera. Eur J Cancer. 2009;45(8):1494-509.

39. Rosario JCJ, Josephine RM. A review on traditional medicinal plants for anticancerous activity. Int J Recent Sci Res. 2015;6(8):5634-7.

40. Van Wyk B-E, van Oudshoorn B, Gericke N. Medicinal plants of South Africa. 2nd ed. Pretoria: Briza Publications; 2009.

41. Muralikrishnan G, Amanullah S, Basha MI, Dinda AK, Shakeel F. Modulating effect of Withania somnifera on TCA cycle enzymes and electron transport chain in azoxymethane-induced colon cancer in mice. Immunopharmacol Immunotoxicol. 2010;32(3):523-7.

42. Mcllwain DR, Berger T, Mak TW. Caspase functions in cell death and disease. Cold Spring Harb Perspect Biol. 2013;5(4):1-28.
43. Rasool M, Varalakshmi P. Immunomodulatory role of Withania somnifera root powder on experimental induced inflammation: an in vivo and in vitro study. Vasc Pharmacol. 2006;44(6):406-10.

44. Dhanani T, Shah S, Gajbhiye NA, Kumar S. Effect of extraction methods on yield, phytochemical constituents and antioxidant activity of Withania somnifera. Arab J Chem. 2017;10:S1193-S9.

45. Dhuley JN. Effect of some Indian herbs on macrophage functions in ochratoxin a treated mice. J Ethnopharmacol. 1997;58(1):15-20.

46. Zechner R, Newman TC, Sherry B, Cerami A, Breslow JL. Recombinant human cachectin/tumor necrosis factor but not interleukin-1 alpha downregulates lipoprotien lipase gene expression at the transcriptional level in mouse 3T3-L1 adipocytes. Mol Cell Biol. 1988;8(6):2394-401.

47. Llovera M, Garcia-Martinez C, Agell N, López-Soriano FJ, Argilés JM. TNF can directly induce the expression of ubiquitin-dependent proteolytic system in rat soleus muscles. Biochem Biophys Res Commun. 1997;230(2):238-41.

48. Russell ST, Rajani S, Dhadda RS, Tisdale MJ. Mechanism of induction of muscle protein loss by hyperglycaemia. Exp Cell Res. 2009;315(1):16-25.

49. Guttridge DC, Mayo MW, Madrid LV, Wang CY, Baldwin ASJ. NF-kB-induced loss of MyoD messenger RNA: possible role in muscle decay and cachexia. Science. 2000;289(5488):2363-6.

50. Fang $Y Z$, Yang $S$, Wu G. Free radicals, antioxidants, and nutrition. Nutrition 2002:18(10):872-9.

51. Wang $X, \mathrm{Hu} Z, \mathrm{Hu} J$, Du J, Mitch WE. Insulin resistance accelerates muscle protein degradation: activation of the ubiquitin- proteasome pathway by defects in muscle cell signaling. Endocrinology. 2006;147(9):4160-8.

\section{Submit your next manuscript to BioMed Central and we will help you at every step:}

- We accept pre-submission inquiries

- Our selector tool helps you to find the most relevant journal

- We provide round the clock customer support

- Convenient online submission

- Thorough peer review

- Inclusion in PubMed and all major indexing services

- Maximum visibility for your research

Submit your manuscript at www.biomedcentral.com/submit
) Biomed Central 